\title{
Contrasting physiological responses to future ocean acidification among Arctic copepod populations
}

Thor, Peter ; Bailey, Allison; Dupont, Sam; Calosi, Piero; Søreide, Janne E; De Wit, Pierre; Guscelli, Ella; Loubet-Sartrou, Lea; Deichmann, Ida Marie; Candee, Martin Milton

Total number of authors:

13

Published in:

Global Change Biology

Link to article, DOI:

$10.1111 / \mathrm{gcb} .13870$

Publication date:

2018

Document Version

Peer reviewed version

Link back to DTU Orbit

Citation (APA):

Thor, P., Bailey, A., Dupont, S., Calosi, P., Søreide, J. E., De Wit, P., Guscelli, E., Loubet-Sartrou, L.,

Deichmann, I. M., Candee, M. M., Svensen, C., King, A. L., \& Bellerby, R. G. J. (2018). Contrasting physiological responses to future ocean acidification among Arctic copepod populations. Global Change Biology, 24(1), 365377. https://doi.org/10.1111/gcb.13870

\section{General rights}

Copyright and moral rights for the publications made accessible in the public portal are retained by the authors and/or other copyright owners and it is a condition of accessing publications that users recognise and abide by the legal requirements associated with these rights.

- Users may download and print one copy of any publication from the public portal for the purpose of private study or research.

- You may not further distribute the material or use it for any profit-making activity or commercial gain

- You may freely distribute the URL identifying the publication in the public portal 


\section{Contrasting physiological responses to future ocean acidification}

\section{2 among Arctic copepod populations}

3 Running head: Contrasting responses to ocean acidification

Peter Thor ${ }^{1}$, Allison Bailey ${ }^{1}$, Sam Dupont ${ }^{2}$, Piero Calosi ${ }^{3}$, Janne E. Søreide ${ }^{4}$, Pierre De Wit ${ }^{5}$, Ella Guscelli ${ }^{6}$, Lea Loubet-Sartrou ${ }^{3}$, Ida Marie Deichmann ${ }^{7}$, Martin M. Candee ${ }^{8}$, Camilla Svensen ${ }^{9}$, Andrew L. King ${ }^{10}$, Richard G.J. Bellerby ${ }^{10,11}$

${ }^{1}$ Norwegian Polar Institute, Fram Centre N-9296 Troms $\varnothing$, Norway.

$10{ }^{2}$ University of Gothenburg, Dept. of Biological and Environmental Sciences, SE-451 78

11 Fiskebäckskil, Sweden.

12 '3niversité du Québec à Rimouski, Département de Biologie, Chimie et Géographie,

13 Rimouski, QC G5L 3A1, Canada

$14{ }^{4}$ University Centre in Svalbard, N-9171 Longyearbyen, Norway

$15{ }^{5}$ University of Gothenburg, Dept. of Marine Sciences, SE-452 96 Strömstad, Sweden.

${ }^{6}$ University of Florence, 50121 Florence, Italy

$17{ }^{7}$ University of Aarhus, Department of Bioscience, DK-8000 Aarhus, Denmark

$18{ }^{8}$ Danish Technical University, DTU-AQUA, DK-2920 Charlottenlund, Denmark

$19{ }^{9}$ UiT The Arctic University of Norway, Faculty of Biosciences, Fisheries and Economics, 209037 Troms $\varnothing$, Norway

$21{ }^{10}$ Norwegian Institute for Water Research, N-5006, Bergen, Norway

$22{ }^{11}$ State Key Laboratory for Estuarine and Coastal Research, East China Normal University, 23 Shanghai 200062, China

Corresponding author: Peter Thor, tel: +47 40613027, peter.thor@npolar.no

Keywords: Ocean acidification, Arctic, zooplankton, metabolic rate, ingestion rate, reaction 
30 Widespread ocean acidification (OA) is modifying the chemistry of the global ocean, and the Arctic is recognised as the region where the changes will progress at the fastest rate. Moreover, Arctic species show lower capacity for cellular homeostasis and acid-base regulation rendering them particularly vulnerable to OA. In the present study, we found physiological differences in OA response across geographically separated populations of Calanus glacialis. In copepodite stage CIV, measured reaction norms of ingestion rate and metabolic rate showed severe reductions in ingestion and increased metabolic expenses in two populations from Svalbard (Kongsfjord and Billefjord) whereas no effects were observed in a population from the Disko Bay, West Greenland. $\mathrm{At}_{\mathrm{pH}}$ 7.87, which has been predicted for the Svalbard west coast by year 2100, these changes resulted in reductions in scope for growth of $19 \%$ in the Kongsfjord and a staggering 50\% in the Billefjord. Interestingly, these effects were not observed in stage $\mathrm{CV}$ copepodites from any of the three locations. It seems that $\mathrm{CV}$ s may be more tolerant to OA perhaps due to a general physiological reorganisation to meet low intracellular $\mathrm{pH}$ during hibernation. Needless to say, the observed changes in the CIV stage will have serious implications for the $C$. glacialis population health status and growth around Svalbard. However, OA tolerant populations such as the one in the Disko Bay could help to alleviate severe effects in $C$. glacialis as a species.

\section{Introduction}

Widespread ocean acidification (OA) is modifying the chemistry of the global ocean (HoeghGuldberg et al., 2014). Driven by an increase in global atmospheric $p \mathrm{CO}_{2}$ from $280 \mu \mathrm{atm}$ at pre-industrial times to the present day $400 \mu \mathrm{atm}$ (IPCC, 2013), the global ocean mean surface $\mathrm{pH}$ has decreased from 8.13 to the present day 8.05. Ocean models predict a continuation of this trend with a further decrease of $0.4 \mathrm{pH}$ units by the year 2100 (Bopp et al., 2013, Caldeira \& Wickett, 2005, Cao et al., 2007). Due to the chemical characteristics of Arctic sea water, the Arctic is recognised as the region where the earliest and strongest decreases in $\mathrm{pH}$ are expected (Fabry et al., 2009, Hoegh-Guldberg et al., 2014, Steinacher et al., 2009). Increasing sea ice melt with low $\mathrm{H}^{+}$buffering capacity makes Arctic waters increasingly susceptible to OA (Yamamoto-Kawai et al., 2009). Moreover, while the Arctic Ocean constitutes only 1\% of the global ocean volume, it receives $11 \%$ of the riverine discharge carrying not only low $\mathrm{H}^{+}$ buffering capacity but also significant loads of terrestrial carbon prone to conversion to $\mathrm{CO}_{2}$ by microbial respiration (Raymond et al., 2007). This input has increased by $7 \%$ since the 
1930s (Peterson et al., 2002). Finally, increasing inflow from the North Atlantic carries large amounts of anthropogenic $\mathrm{CO}_{2}$ to the Arctic Ocean (Fransson et al., 2001).

The magnitude of predicted chemical changes due to OA extends beyond anything experienced by most extant species (Fabry et al., 2008) and significant effects are predicted for many marine animals (Dupont \& Pörtner, 2013, Wittmann \& Pörtner, 2013). But while effects may be severe locally, they may vary across geographic ranges and among populations (Wood et al., 2016). While it has long been hypothesised that long distance dispersal of planktonic larvae and eggs in an environment with few physical barriers has rendered most marine species genetically homogeneous over long distances, recent studies of marine invertebrates, including planktonic species, show geographically structured populations and isolation on the scale of ocean basins and adjacent seas (Hellberg, 2009, Peijnenburg \& Goetze, 2013, Sanford \& Kelly, 2010). Such structuring increases the possibility for differential physiological responses to environmental changes to develop among hydrographic provinces (as shown at lower latitudes by Calosi et al., 2017, Vargas et al., 2017). Differential responses carry with them a possibility that affected species may be relieved from severe effects and extinction (Calosi et al., 2016, Sunday et al., 2014). Effects may be severe locally, and possibly lead to local extinction, but other enclaves may show higher tolerance.

Naturally, relief from environmental change is all the more important for the future of more environmentally sensitive species, and energetic studies suggest that the capacity to counter negative effects of OA could be particularly low in Arctic species. Contrary to cold adapted eurythermal animals, true Polar species show low energetic costs for maintenance (Clarke, 1980, Rastrick \& Whiteley, 2011). While this is an evolutionary strategy to enhance growth at limited aerobic scope, lower allocation to cover maintenance costs also reduce the capacity for energy demanding cellular homeostasis and acid-base regulation (Whiteley, 2011). Moreover, because Arctic communities are characterised by simpler food webs - fewer trophic levels and fewer species occupying each trophic level - they experience reduced overall resilience to environmental changes (AMAP, 2013).

Calanoid copepods, particularly of the Calanus genus, constitute keystone species in the Arctic pelagic community (Grainger, 1965, Møller et al., 2006, Thor et al., 2005). In most pelagic communities, these crustaceans constitute $80 \%$ of the zooplankton biomass, and they are the dominant component of prey for the larvae of most fish species (Last, 1980).

Consequently, their presence is fundamental to many fish populations and studies have shown that larval survival and recruitment of such species as cod (Gadus morhua) and mackerel 
(Scomber scombrus) co-vary with copepod abundance and biomass (Beaugrand et al., 2003, Castonguay et al., 2008, Runge et al., 1999). Any negative effects of environmental changes will therefore have severe repercussions far beyond the copepod populations themselves. For instance, increase in rainfall since the 1980s and lack of intrusion of high saline water from the North Sea have affected reproduction and maturation in the copepod Pseudocalanus elongatus in the Baltic Sea deep basins (Möllmann et al., 2003). This has forced herring (Clupea harengus) to revert to less favourable prey imposing serious implications for their development and population growth (Möllmann et al., 2003).

In the present study we investigated the possible existence of differential responses to OA among geographically separated populations of Calanus glacialis, a species which dominates the shelf of the Arctic Ocean and adjacent seas (Wassmann et al., 2015). We established physiological reaction norms across a $\mathrm{pH}$ gradient covering present and predicted future environmental $\mathrm{pH}$ variability for Arctic continental shelf seas. Physiological response was measured as the balance between energy intake and expenditure because it is this balance that determines energetic performance and ultimately fitness in heterotrophs (Brown et al., 2004).

\section{Methods}

\section{Collection of copepods}

Copepods were caught by vertical tows of a $200 \mu \mathrm{m}$ WP2 net equipped with a closed cod end from $100 \mathrm{~m}$ to the surface in the Kongsfjord, Svalbard $\left(79.0^{\circ} \mathrm{N}, 11.7^{\circ} \mathrm{E}\right)$, the Billefjord, Svalbard $\left(78.6^{\circ} \mathrm{N}, 16.5^{\circ} \mathrm{E}\right)$, and the Disko Bay, Western Greenland $\left(69^{\circ} 15^{\prime} \mathrm{N}, 53^{\circ} 33^{\prime} \mathrm{W}\right)$ during July 2015 (Fig. 1). On deck, the content of the cod end was diluted in 25 L seawater collected at $80 \mathrm{~m}$. Copepods were then transported to cold rooms $\left(5^{\circ} \mathrm{C}\right)$ at either the Kings Bay Marine Laboratory (Ny-Ålesund, Svalbard) or the Arctic Station Laboratory (Qeqertarsuaq, Western Greenland). Calanus glacialis copepodites stages III, IV, and V (hereafter CIII, CIV, and CV) were selected under the stereomicroscope using cut off plastic Pasteur pipettes, keeping all vessels on ice to avoid high temperatures. Copepodite stages were identified by number of pleopods and abdominal segments (Mauchline, 1998). They were distinguished from Calanus hyperboreus and Calanus finmarchicus copepodites on the basis of prosome size (Arnkværn et al., 2005, Thor et al., 2008), by red pigmentation in the antennules, which $C$. finmarchicus most often do not have (Nielsen et al., 2014), and the lack of lateral spikes on the distal prosome segment, which is a characteristic of $C$. hyperboreus (Klekowski \& Weslawski, 1991). 
127 We applied a regression design approach, exposing independent samples of copepods to one of seven to nine $\mathrm{pH}$ levels (Table 1). This approach has the advantage of enhanced predictive power compared to the character state approach, which compares effects among different distinct future climate scenarios (Havenhand et al., 2010). We found CIIIs only in the Kongsfjord population, whilst CIVs and CVs were found at all three locations. However, CVs were found in very low numbers in the Billefjord population. After removal of replicates containing incorrectly stage determined individuals (as determined from photographs), individuals with very aberrant prosome length also indicative of erroneous stage determination or speciation, and individuals judged dead after incubations, a total of 153 replicates of ingestion rate measurements and 170 replicates of metabolic rate measurements remained (Table 1).

\section{Preparation of incubation water}

139 For the initiation of incubations and at each water change, five litre batches of incubation water for each treatment were prepared by mixing $0.3 \mu \mathrm{m}$ filtered seawater $\left(f_{s w}\right)$ with small volumes of $f s w$ acidified to ca. $\mathrm{pH} 5.5$ by $\mathrm{CO}_{2}$ bubbling (Mapcon@ $\mathrm{CO}_{2}$, Yara Praxair, Troms $\emptyset$, Norway). This method for manipulating seawater carbonate chemistry has been previously described and validated (Riebesell et al., 2010). The different treatments were established at target $\mathrm{pH}_{\mathrm{T}}\left(\mathrm{pH}\right.$ on the total scale) increments of 0.2 . Total alkalinity $\left(\mathrm{A}_{\mathrm{T}}\right)$ was analysed by potentiometric titration (Dickson et al., 2007) in an open cell with $0.1 \mathrm{M} \mathrm{HCl}$ using a VINDTA 042 carbonate titrator (Marianda, Germany) and total dissolved inorganic carbon $\left(\mathrm{C}_{\mathrm{T}}\right)$ was analysed by coulometric titration (Dickson et al., 2007) using a coulometer (CM5015, UIC, Joliet, IL, USA) connected to the VINDTA after acidification with $8.5 \%$ phosphoric acid. $\mathrm{pCO}_{2}$ and $\mathrm{pH}_{\mathrm{T}}$ were calculated using CO2SYS (Pierrot et al., 2006) with constants from Mehrbach et al. (1973) refitted by Dickson and Millero (1987) and inputs of temperature, salinity, $\mathrm{A}_{\mathrm{T}}$, and $\mathrm{C}_{\mathrm{T}}$. $\mathrm{pH}_{\mathrm{T}}$ was monitored using a SevenGo $\mathrm{SG} 2 \mathrm{pH}$ meter equipped with an InLab 413 SG/2m electrode (Mettler-Toledo, Columbus, Ohio, USA)

153 (Svalbard populations) or a HI 98183 pH/ORP meter (Hanna, Woonsocket, Rhode Island,

154 USA) (Disko Bay population). Determination of $\mathrm{pH}_{\mathrm{T}}$ in all incubation water batches and

155 incubation bottles were based on a standard curve established from simultaneous

156 measurements in water samples of electric potential $(\mathrm{mV})$ with the $\mathrm{pH}$ electrodes and 157 determination of $\mathrm{pH}_{\mathrm{T}}$ from $\mathrm{A}_{\mathrm{T}}$ and $\mathrm{C}_{\mathrm{T}}$ with the VINDTA in the $\mathrm{pH}$ range 8.2-6.4. Salinity and temperature were measured using a conductimeter (Cond 340i, WTW, Weilheim, Germany). 
159 Measured values of chemistry parameters are shown in Table 2. $\mathrm{A}_{\mathrm{T}}$ was established only once

160 for the Billefjord population. For food, paste of the diatom Thalassiosira weissflogii (Tw

161 1200, Reed Mariculture, Campbell, CA, USA) was added to a final concentration of ca. $10 \mu \mathrm{g}$

$162 \mathrm{Chl} a \mathrm{~L}^{-1}$. The necessary dilution of the algal paste was established from the Chl $a$ content of

163 the algal paste determined spectrophotometrically (UV-2401 PC, Shimadzu Co., Kyoto,

164 Japan) after overnight extraction in $70 \%$ ethanol (Strickland \& Parsons, 1972). Prior to

165 incubations, the suitability of the algal paste as prey for $C$. glacialis was assured by

166 comparing faecal pellet counts from incubations of copepodites with previous counts from

167 copepodites incubated at similar concentrations of algae.

\section{Copepod incubations}

169 For each experiment, copepodites were incubated for a total of $8 \mathrm{~d}$ ( $7 \mathrm{~d}$ incubation plus 1 day 170 ingestion rate measurements). For each replicate, 10 individuals were pipetted, using cut off 171 plastic Pasteur pipettes, into a $600 \mathrm{~mL}$ glass Duran bottles prepared with incubation water. All 172 bottles were closed, making sure no air bubbles were present, and placed on a slowly rotating 173 plankton wheel $(0.5 \mathrm{rpm})$ at ca. $5{ }^{\circ} \mathrm{C}$ in dim light. Every day approximately $500 \mathrm{~mL}$ water was 174 replaced in each bottle by inserting a piece of pipe fitted with a $200 \mu \mathrm{m}$ screen at the bottom,

175 siphoning off the water from inside the tube, and replacing it with water from the pre-

176 prepared five litre incubation water batches at the appropriate $\mathrm{pH}$. Samples for $\mathrm{A}_{\mathrm{T}}$ and $\mathrm{C}_{\mathrm{T}}$ 177 were taken from the incubation water batches and from water pooled from all bottles of each 178 treatment subsequent to the incubations on days 2,5 , and 8).

\section{Measurement of ingestion and metabolic rates}

180 On day 7, five additional control bottles without copepods were prepared with incubation 181 water for estimates of ingestion rates. Triplicate samples for Chl $a$ determination were taken 182 from each incubation water batch. On day 8 the content of each bottle was poured through a $18320 \mu \mathrm{m}$ sieve held in a Petri dish to remove copepods, faecal pellets, and eggs. While doing 184 this, the water was collected in a beaker from under the Petri dish and $200 \mathrm{~mL}$ was filtered 185 onto a $0.7 \mu \mathrm{m}$ glass fiber filter (Whatman, GF/F, Maidstone, $\mathrm{UK}$ ) which was frozen for later 186 Chl $a$ determination. The content of the $20 \mu \mathrm{m}$ sieve was gently flushed into a Petri dish and 187 copepods for metabolic rate measurements were collected. The rest were counted and 188 photographed for precise determination of developmental stage under the stereoscope.

189 For estimates of specific metabolic rate $\left(\dot{M} \mathrm{O}_{2}\right)$, oxygen consumption rates were measured on

190 individual copepodites according to Thor and Oliva (2015). One individual from each bottle 
was pipetted from the Petri dish into a $1.6 \mathrm{~mL}$ vial fitted with fluorescent $\mathrm{O}_{2}$ reactive foil discs (PSt3 spots, PreSens, Regensburg, Germany) and filled with $f s w$, which had been saturated with air by vigorous bubbling and adjusted to the corresponding $\mathrm{pH}$. Vials were then sealed with Teflon caps and after a resting period of ca. 30 min to acclimate copepods $\mathrm{O}_{2}$ concentrations were measured at 0, 2.5, and 5 h using an optode $\mathrm{O}_{2}$ system (Fibox 3, PreSens, Regensburg, Germany). $\mathrm{O}_{2}$ consumption rate ( $\mathrm{nmol} \mathrm{O}$ ind $^{-1} \mathrm{~d}^{-1}$ ) was calculated by subtracting the average $\mathrm{O}_{2}$ depletion rate measured in the five controls without copepods from the $\mathrm{O}_{2}$ depletion rate in each of the copepod containing vials ( nmol O$\left._{2} \mathrm{~L}^{-1} \mathrm{~h}^{-1}\right)$ and multiplying by vial volume (L) and $24 \mathrm{~h} \mathrm{~d}^{-1}$. Prior testing of the optode system at $5{ }^{\circ} \mathrm{C}$ showed a 3 -min $95 \%$ reaction time, i.e. the period of time taken before the output reached within $5 \%$ of the final $\mathrm{O}_{2}$ concentration value (as estimated by exponential regression). Therefore, at every sampling event, $\mathrm{O}_{2}$ concentration was read for $3 \mathrm{~min}$, and an average of values read during the last minute was used for calculations. Subsequent to the measurements the copepods were transferred to Petri dishes and photographed under the stereoscope for detailed stage determination.

For estimates of ingestion rate, phytoplankton Chl $a$ concentrations of all samples were determined fluorometrically. The frozen filters were extracted in $4 \mathrm{~mL}$ acetone overnight and fluorescence was measured on a Turner Designs 10-AU fluorometer (Strickland \& Parsons, 1972). Ingestion rate ( $\mu \mathrm{g} \mathrm{Chl} a$ ind $^{-1} \mathrm{~d}^{-1}$ ) was calculated from the decrease in Chl $a$ concentrations from all bottles containing copepods subtracted by the decrease in disappearance from the control bottles ( $\mu \mathrm{g} \mathrm{Chl} a \mathrm{~L}^{-1} \mathrm{~d}^{-1}$ ) (Frost, 1972), multiplying by bottle volume (L), and dividing by number of copepods counted in the bottles at day 8 .

To obtain weight specific rates, copepod prosome lengths were measured from the photographs using ImageJ (U. S. National Institutes of Health) and body carbon weights were calculated using a weight/length relationship of $\mathrm{W}(\mu \mathrm{gC})=4.8 \mathrm{~L}(\mathrm{~mm})^{3.57}$ (Madsen et al., 2001). Oxygen consumption rates (nmol $\mathrm{O}_{2}$ ind $\left.^{-1} \mathrm{~h}^{-1}\right)$ were converted to specific metabolic rate $\left(\dot{M} \mathrm{O}_{2}, \mu \mathrm{gC} \mu \mathrm{gC}^{-1} \mathrm{~d}^{-1}\right)$ by dividing by body mass $\left(\mu \mathrm{gC} \mathrm{ind}^{-1}\right)$, multiplying by a respiratory coefficient of $0.97 \mathrm{~mol} \mathrm{C}$ mol O${ }_{2}^{-1}$ (Omori \& Ikeda, 1984), multiplying by $0.012 \mu \mathrm{gC} \mathrm{nmol} \mathrm{C^{- }}$ ${ }^{1}$, and multiplying by $24 \mathrm{~h} \mathrm{~d}^{-1}$. Ingestion rates (ng Chl $a$ ind $^{-1} \mathrm{~d}^{-1}$ ) were converted to specific ingestion rate $\left(I R, \mu \mathrm{gC} \mu \mathrm{gC}^{-1} \mathrm{~d}^{-1}\right)$ by multiplying by $50 \mu \mathrm{gC} \mu \mathrm{g} \mathrm{Chl} a^{-1}$ (Båmstedt et al., 2000) and dividing by body mass $\left(\mu \mathrm{gC}\right.$ ind $\left.^{-1}\right)$. 
To avoid bias from differences in temperature among incubations, all rates were normalized

223 to the average temperature of $5.2^{\circ} \mathrm{C}$ using a $\mathrm{Q}_{10}$ value of 2.0 for metabolic rate in marine copepods (Ikeda et al., 2001).

\section{Data analysis and determination of reaction norms}

226 Since treatments were evenly distributed along $\mathrm{pH}$ reaction norms for each population and copepodite stage, rates would be inherently non-normally distributed when reaction norms show significant slopes. For comparisons of mean rates (i.e. the average rate of all individuals from all $\mathrm{pH}$ treatments) among populations and stages we therefore used a 2-factor permutational analysis of variance test (PERMANOVA) on similarity matrices assembled using Euclidian distances (Anderson, 2001). Prosome lengths were similarly compared among populations and stages using a 2-factor PERMANOVA.

233 For each copepodite stage in each population, $\mathrm{pH}$ reaction norms of ingestion rate and

234 metabolic rate were established by sequentially testing polynomial regression models of 235 increasing order (linear, quadratic, or cubic) for the relationship between the variable and $\mathrm{pH}_{\mathrm{T}}$ 236 according to David et al. (1997). Best fitting models were chosen by statistically comparing 237 sums of squares among the three models as

$$
F_{1, d f}=\frac{S S_{\text {higher }}-S S_{\text {lower }}}{M S_{\text {res }}}
$$

where $d f$ is the degree of freedom of the higher degree model, $S S_{\text {higher }}$ is the sums of squares of the higher degree model, $S S_{\text {lower }}$ is the sums of squares of the lower degree model, and $M S_{\text {res }}$ is the residual mean squares of the higher degree model (Rocha \& Klaczko, 2012).

After assuring homoscedasticity (Levene's test), reaction norms of specific rates were compared among populations using univariate general linear model analysis (GLM) in SPSS (IBM Inc.). Differences of level among populations were detected by significant differences among populations using a $\mathrm{pH}_{\mathrm{T}}+$ population design, and differences of slopes were detected by significant interactions of $\mathrm{pH}_{\mathrm{T}}$ and population using $\mathrm{pH}$ as the covariate in a $\mathrm{pH}_{\mathrm{T}}+$ population + population $\mathrm{x} \mathrm{pH}_{\mathrm{T}}$ design.

248 To evaluate the overall physiological effects of decreasing $\mathrm{pH}_{\mathrm{T}}$, scope for growth values were 249 constructed from relationships between metabolic rate and ingestion rate in CIVs. Since metabolic rates were measured on different individuals than ingestion rate, no direct comparison was possible and we therefore calculated mean predicted scope for growth values 
$252(\widehat{S F G})$ at each $\mathrm{pH}_{\mathrm{T}}$ on the basis of predicted rates from the reaction norm regressions as

$253 \widehat{S F G}=\widehat{I R} \times A E-\widehat{\dot{M}} O_{2}$, where $A E$ is absorption efficiency, which was set at 0.6 for

254 copepods (Thor et al., 2007, Thor \& Wendt, 2010).

\section{Results}

\section{Comparison of mean rates among populations and developmental stages}

Although prosome lengths were measure purely to enable calculation of weight specific rates, we found significant differences in these among populations (unrelated to $\mathrm{pH}$ ) and therefore report the analyses here. Prosome lengths of both stage CIV and CV copepodites differed significantly among the three populations (2-factor PERMANOVA: pseudo- $\mathrm{F}_{2,335}=32.2, P<$ 0.001). CIVs were significantly larger in the Kongsfjord and Disko Bay populations (2532 \pm $381 \mu \mathrm{m}$ and $2510 \pm 115 \mu \mathrm{m}$, mean $\pm \mathrm{sd}$ ), respectively, than in the Billefjord population (2338 $\pm 150 \mu \mathrm{m})(2$-factor PERMANOVA pair-wise test: $P<0.001)$, whereas CVs were significantly larger in the Disko Bay population $(3357 \pm 144 \mu \mathrm{m})$ than in the Kongsfjord and Billefjord populations (2962 $\pm 307 \mu \mathrm{m}$ and $2875 \pm 313 \mu \mathrm{m}$, respectively) (2-factor PERMANOVA pair-wise test, $\mathrm{P}<0.001)$.

The mean specific ingestion rate of the three developmental stages (for each stage, the average rate of all individuals from all $\mathrm{pH}_{\mathrm{T}}$ tested) were significantly different at $0.111 \pm$ $0.042 \mu \mathrm{gC} \mu \mathrm{gC}^{-1} \mathrm{~d}^{-1}$ in CIIIs, $0.044 \pm 0.021 \mu \mathrm{gC} \mu \mathrm{gC}^{-1} \mathrm{~d}^{-1}$ in CIVs, and $0.021 \pm 0.011 \mu \mathrm{gC}$ $\mu \mathrm{gC}^{-1} \mathrm{~d}^{-1}$ in CVs (2-factor PERMANOVA: pseudo- $\mathrm{F}_{2,152}=54.6, P<0.001$ ). Mean rates (for each population, the average rate of all individuals from all $\mathrm{pH}_{\mathrm{T}}$ tested) also differed significantly between the Kongsfjord and Disko Bay populations (2-factor PERMANOVA pairwise test: $P=0.004)$ mainly due to the larger size and calculated weight, and hence lower specific rates, of CVs in the Disko Bay population.

Similarly, mean specific metabolic rates were significantly different among developmental stages: $0.025 \pm 0.018 \mu \mathrm{gC} \mu \mathrm{gC}^{-1} \mathrm{~d}^{-1}$ in CIIIs, $0.024 \pm 0.009 \mu \mathrm{gC} \mu \mathrm{gC}^{-1} \mathrm{~d}^{-1}$ in CIVs, and 0.015 $\pm 0.006 \mu \mathrm{gC} \mu \mathrm{gC}^{-1} \mathrm{~d}^{-1}$ in CVs (2-factor PERMANOVA: pseudo-F2,169=14.3, $P<0.001$ ).

These differed among populations with significantly lower rates in the Disko Bay population than in the two Svalbard populations (2-factor PERMANOVA pairwise tests: $P<0.02$ ).

\section{Ingestion rate reaction norms}

In CIVs ingestion rates decreased by $85 \%$ and $66 \%$ from the highest to the lowest $\mathrm{pH}_{\mathrm{T}}$, in the Kongsfjord and Billefjord populations respectively, but remained unchanged in CIV from the 
283

284

285

286

287

288

289

290

291

292

293

294

295

296

297

298

299

300

301

302

303

304

305

306

307

308

309

310

311

312

313

Disko Bay population (Figs. 2a,b,c). Ingestion rate reaction norms showed linearly decreasing rates with decreasing $\mathrm{pH}_{\mathrm{T}}$ in CIVs from the Kongsfjord and Billefjord populations (Table 3).

There was no difference in slopes between the Kongsfjord and Billefjord populations (GLM, comparison of slopes: $\left.\mathrm{F}_{1,52}=0.61, \mathrm{P}=0.439\right)$.

In CIIIs from the Kongsfjord population, ingestion rates first increased by 53\% from the highest $\mathrm{pH}_{\mathrm{T}}$ to $\mathrm{pH}_{\mathrm{T}} 7.337$ and then decreased to $33 \%$ at the lowest $\mathrm{pH}_{\mathrm{T}}$ compared to the rate at the highest $\mathrm{pH}_{\mathrm{T}}$ (Fig. 2d). These changes were better fitted with the second order regression, $I R=\max I R+g_{2}\left(p H_{T}-p H_{T \max I R}\right)^{2}$, where maximum ingestion rate $(\max I R)$ was 0.124 $\mu \mathrm{gC} \mu \mathrm{gC}^{-1} \mathrm{~d}^{-1}, \mathrm{pH}_{\mathrm{T}}$ at maximum ingestion rate $\left(p H_{\text {TmaxIR }}\right)$ was 7.41 , and the slope, $g_{2}$, was $0.099\left(r^{2}=0.39, \mathrm{P}=0.019\right)($ Fig. 2d).

There were no significant effect of $\mathrm{pH}_{\mathrm{T}}$ on ingestion rates of $\mathrm{CV}$ s from any of the three populations (Table 3; Fig 3).

\section{Metabolic rate reaction norms}

Metabolic rates increased by $136 \%$ and $127 \%$ from high to low $\mathrm{pH}_{\mathrm{T}}$ in CIVs from the Kongsfjord and Billefjord populations, respectively, but remained unchanged in CIVs from the Disko Bay population (Figs. 2a,b,c). The metabolic reaction norms showed significant linearly increasing metabolic rates in Kongsfjord and Billefjord CIVs (Table 4) but there were no differences in slopes of metabolic rate reaction norms between in the Kongsfjord and Billefjord population CIVs (GLM pairwise comparison of slopes: $\mathrm{F}_{1,48}=1.30, \mathrm{P}=0.260$ ),

Metabolic rates remained unchanged with decreasing $\mathrm{pH}_{\mathrm{T}}$ in CIIIs (Table 4; Fig. 2d), and in CVs from all three populations (Table 4; Fig. 3).

Temperatures were generally lower in the Disko Bay experiments. Correction for temperature differences among locations changed rates by an average $8 \%$. These corrections did not significantly affect reaction norm slopes (GLM analysis comparing slopes of all reaction norms with and without temperature corrections: $\mathrm{P}<0.05)$.

\section{Scope for growth}

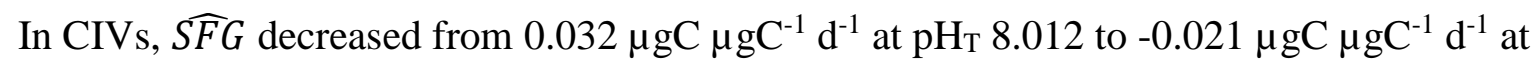
$\mathrm{pH}_{\mathrm{T}} 6.445$ in the Kongsfjord population and from 0.010 at $\mathrm{pH}_{\mathrm{T}} 8.041$ to $-0.018 \mu \mathrm{gC} \mathrm{gC}^{-1} \mathrm{~d}^{-1}$ at $\mathrm{pH}_{\mathrm{T}} 7.036$ in the Billefjord population. Thus, $\widehat{S F G}$ became negative below $\mathrm{pH}_{\mathrm{T}} 7.04$ in CIVs from the Kongsfjord population but already at $\mathrm{pH}_{\mathrm{T}} 7.67$ in CIVs from the Billefjord population. 
314 In CIIIs from the Kongsfjord population predicted scope for growth $(\widehat{S F G})$ first increased 315 from $0.025 \mu \mathrm{gC} \mu \mathrm{gC}^{-1} \mathrm{~d}^{-1}$ at $\mathrm{pH}_{\mathrm{T}} 8.041$ to $0.049 \mu \mathrm{gC} \mu \mathrm{gC}^{-1} \mathrm{~d}^{-1}$ at $\mathrm{pH}_{\mathrm{T}} 7.333$ and then 316 decreased to $-0.009 \mu \mathrm{gC} \mu \mathrm{gC}^{-1} \mathrm{~d}^{-1}$ at $\mathrm{pH}_{\mathrm{T}} 6.421$.

317 We did not calculate $\widehat{S F G}$ changes in CVs since neither ingestion rates not metabolic rates 318 changed significantly with $\mathrm{pH}_{\mathrm{T}}$. Any calculated differences would stem from stochastic 319 differences or sampling variability rather than real physiological changes.

\section{Discussion}

321 The balance between energy intake and energy expenditure is the prime determinant of 322 survival in any heterotrophic organism. Energy intake has to be sufficient to cover 323 maintenance and repair costs, as well as costs for growth or reproduction for an organism to 324 uphold positive Darwinian fitness (Sibly \& Calow, 1986). In the present study, we observed 325 severe reductions in ingestion rate along with increased metabolic rates with decreasing $\mathrm{pH}_{\mathrm{T}}$ 326 in Calanus glacialis copepodite stage CIV from two Svalbard populations (Kongsfjord and 327 Billefjord), but not in CIVs from the Disko Bay, West Greenland. These effects were limited 328 to the CIV stage and there were no effects in stage CV copepodites from any of the three 329 populations. Nevertheless, at $\mathrm{pH}_{\mathrm{T}}$ 7.87, which has been predicted for the Svalbard west coast 330 by the year 2100 (Bellerby et al., 2012), scope for growth decreased by $19 \%$ in the

331 Kongsfjord CIVs, while in the Billefjord CIVs it decreased by a staggering 50\%. In fact, these 332 estimates of scope for growth may be conservative since absorption efficiency may decrease 333 with decreasing $\mathrm{pH}$ due to decreasing gut enzyme activity (Stumpp et al., 2013). Needless to 334 say, such changes will have serious implications for the $C$. glacialis population around 335 Svalbard. Reductions in scope for growth on this scale will prolong stage development time 336 and reduce the individual body size of the developing copepodites and ultimately also reduce 337 adult body size. This effect has been observed in Calanus helgolandicus cohorts reared in 338 mesocosms at low prey levels (Rey-Rassat et al., 2002). The resulting reduction in adult body 339 size will entail decreased egg production rates (Halvorsen, 2015), and there is a real risk that 340 these effects, although possibly limited to one or a few specific copepodite stages (Kongfjord 341 CIIIs showed a peaking ingestion rate reaction norm), may impair the general health status 342 and growth of $C$. glacialis in this region. Accordingly, studies in the North Sea and the sub343 Arctic Pacific have shown that similar changes in spring juvenile production have significant 344 effects on overall population development. A long-term sampling series in the North Sea has 345 shown that years with low larval growth during spring results in lower summer biomass than 
years with higher spring larval growth (Clark et al., 2003). Similar variations have been observed in the sub-Arctic Pacific Neocalanus plumchrus population. This population experiences significant inter-decadal variations in peak summer biomass, which is hypothesised to stem from changes in copepodite growth rate during spring (Mackas et al., 1998).

Previous studies have shown metabolic effects of low $\mathrm{pH}$ on copepods, although results are far from conclusive. Metabolic rate increased significantly by $28 \%$ from $\mathrm{pH}_{\mathrm{NBS}}$ (National Bureau of Standards scale) 8.18 to 7.83 in Centropages tenuiremis (no developmental stage indicated) (Li \& Gao, 2012) and in Pseudocalanus acuspes females it increased significantly by $11 \%$ from $\mathrm{pH}_{\mathrm{T}} 8.06$ to 7.75 (Thor \& Dupont, 2015). Metabolic rates doubled from $\mathrm{pH}_{\mathrm{T}}$ 8.06 to $\mathrm{pH}_{\mathrm{T}} 7.66$ in Acartia grani females, although low replication rendered the difference non-significant, whereas no clear effect was observed in female A. clausi exposed to $\mathrm{pH}_{\mathrm{T}} 8.03$ and $\mathrm{pH}_{\mathrm{T}} 7.83$ (Isari et al., 2015, Zervoudaki et al., 2014). In Pseudocalanus acuspes a decrease from $7.95 \mathrm{pH}_{\mathrm{T}}$ to 7.61 showed no clear effect on metabolic rate in a population from Svalbard, whereas a population from Skagerrak experienced significant changes (Thor \& Oliva, 2015). But these changes depended on food level and no clear response could be concluded. The lack of response of $C$. glacialis $\mathrm{CVs}$ in the present study is corroborated by a recent study in the Kongsfjord (Thor et al., 2016) and has also been shown to last during longer-term incubations where metabolic rates remained equal in $C$. glacialis $\mathrm{CVs}$ and $C$. hyperboreus $\mathrm{CVs}$ and females incubated at $\mathrm{pH}_{\mathrm{F}}$ (free scale $\mathrm{pH}$ ) 8.13 and 7.26 for 62 days (Hildebrandt et al., 2014). Metabolic rates of CVs increased linearly across a range from $\mathrm{pH}_{\mathrm{T}}$ 8.02 to $\mathrm{pH}_{\mathrm{T}} 7.16$ in a study on culture reared $C$. finmarchicus applying reaction norm statistics similar to the present study (Pedersen et al., 2014), whereas a later study found no effects between $\mathrm{pH}_{\mathrm{T}} 7.92$ and $\mathrm{pH}_{\mathrm{T}} 7.51$ in wild caught $C$. finmarchicus $\mathrm{CV}$ s and females (Runge $e t$ al., 2016). Ingestion rates have been shown to be unresponsive in A. grani and Oithona davisae females (Isari et al., 2015). In the Calanus genus, C. finmarchicus and C. glacialis CVs showed no changes in ingestion rates when exposed at $\mathrm{pH}_{\mathrm{T}} 7.2$ (Hildebrandt et al., 373 2016).

374 Geographically specific responses to low $\mathrm{pH}$ exposure have been demonstrated in several marine species. The metabolic response to low $\mathrm{pH}$ varies with latitude in the gastropod

376 Littorina littorea showing an upregulation in the centre of the species distribution along the 377 European continental coast but a decrease in the southern- and northern-most regions (Calosi 378 et al., 2017). Such latitudinal differences also occur in the calanoid copepod Acartia tonsa, 
larvae of the gastropod Concholepas concholepas, and the bivalve Perumytilus purpuratus

380 along the Chilean coast (Vargas et al., 2017). While ingestion rates did not change with decreased $\mathrm{pH}$ in $\mathrm{A}$. tonsa originating from an estuary with low and variable $\mathrm{pH}$, they decreased by $72 \%$ in individuals from a coastal ocean area with perpetual high $\mathrm{pH}$ (Vargas et al., 2017). Geographically specific responses have been observed also in another calanoid copepod species, Pseudocalanus acuspes. Populations from the Kongsfjord and the Gullmarsfjord (Swedish west coast) showed differences in the relationship between ingestion rate and metabolic rate (Thor \& Oliva, 2015). Low pH induced a steeper increase in metabolic rate with increasing ingestion rate in females of the Swedish population than in females of the Svalbard population. Also the isopod Idotea balthica has shown geographically specific OA responses. In this case, metabolic rate and osmoregulatory activity responded differently to increased $\mathrm{pCO}_{2}(1000 \mu \mathrm{atm})$ in individuals originating from low and high salinity environments (Wood et al., 2016). Likewise, larvae of the spider crab Hyas araneus have shown differences in growth responses between two populations from Svalbard and the North Sea (Walther et al., 2010). These differences may be a reflection of a general ability of the tested species for physiological plasticity to counter $\mathrm{pH}$ variations. Such plasticity may originate from the environment of the individual's habitat (phenotypic plasticity) or from the environment experienced by previous generations (transgenerational plasticity). But they may also arise from genetic adaptation to different $\mathrm{pH}$ environments among locations. Evidence for rapid evolution in the face of fast environmental changes is increasing (Carroll et al., 2007), and previous studies have shown that calanoid copepods have the capacity for fast adaptation to low $\mathrm{pH}$ conditions. While our experimental design, incubations for less than one generation, did not allow detection of local adaption, Thor and Dupont (2015) found adaptation causing changes in Pseudocalanus acuspes fecundity after only two generations at $\mathrm{pH}_{\mathrm{T}} 7.54$, which could be linked to observed selection in genes coding for processes involved in oxidative phosphorylation and ribosomal structure (De Wit et al., 2015). Similarly, in echinoderms low $\mathrm{pH} /$ high $p \mathrm{CO}_{2}$ has been observed to induce rapid selection in genes coding for biomineralization, lipid metabolism, and ion homeostasis (Pespeni et al., 2013). However, in the very same study on P. acuspes, Thor and Dupont (2015) also found evidence of phenotypic plasticity in response to lowered $\mathrm{pH}$, albeit at lower levels of $\mathrm{pH}$ reductions, so both mechanisms may act in concert to alleviate OA effects. Regardless of the origin of the observed geographic differences in the CIV copepodites, phenotypic plasticity, transgenerational plasticity, or local adaptation, they have specific consequences for the future of $C$. glacialis as a species. The severe reductions in scope for growth in this stage observed 
413 in the Svalbard populations would render C. glacialis with little potential to survive future

414 OA. However, the existence of enclaves or perhaps extended populations with increased 415 tolerance, such as the Disko Bay population, could prove important as an alleviating factor to 416 remove or at least delay future OA effects.

417 Tolerance to certain environmental conditions is developed through pre-exposure. The few 418 existing studies reveal a possible difference between the Disko Bay and the Svalbard fjords 419 with respect to carbonate chemistry. While the Davis Strait outside Disko Bay exhibits similar 420 high pH, as is common in Arctic waters (Azetsu-Scott et al., 2010), the water of the Disko 421 Bay may be somewhat special. The Disko Bay is influenced by extensive glacial discharge 422 from the Jakobshavn glacier, and during summer the surface water are characterised by the 423 balance between melt water production and the inflow of water from the West Greenland 424 Current (Hansen et al., 2012). Hence, the Disko Bay is very variable environment both on a 425 seasonal and inter-annual scale. Studies from 2011 and 2012 showed that while $\mathrm{pH}_{\mathrm{NBS}}$ was 426 mostly high at the surface, it was perpetually lower than 8.0 below $50 \mathrm{~m}$ with values approaching 7.5 during May (Riisgaard et al., 2015, Thoisen et al., 2015). Frequently, low pH water was encountered throughout the water column during May in both years studied. $\mathrm{pH}_{\mathrm{NBS}}$ did increase during the spring bloom but re-attained values below 8.0 immediately after the termination of the bloom (Riisgaard et al., 2015). Outside the spring bloom period, $\mathrm{pH}_{\mathrm{NBS}}$ was in the range 7.6-7.9 at fluorescence max depth, the depth where most copepods reside when feeding. The Kongsfjord is probably the best studied of the three, and recent investigations show high $\mathrm{pH} /$ low $p \mathrm{CO}_{2}$ conditions throughout the fjord during summer and possibly also during winter (Fransson et al., 2016). $\mathrm{pH}_{\mathrm{T}}$ remained above 8.0 throughout the water column during July of the two consecutive years 2013 and 2014, and although winter data are scarcer, minimum measured winter surface water $\mathrm{pH}_{\mathrm{T}}$ values in the Kongsfjord were 8.11 in 2013 and 8.14 in 2014 (Fransson et al., 2016). To our knowledge there is no information on carbonate chemistry from the Billefjord. Thus, contrary to the Kongsfjord (and perhaps also the Billefjord), it seems that there would be a real possibility for zooplankton in the Disko Bay to be frequently exposed to low $\mathrm{pH}$ conditions during spring and summer, the period for copepodite growth (Yamamoto-Kawai et al., 2009).

Is tolerance of low $\mathrm{pH}$ a special characteristic of the Disko Bay population or could we expect enclaves with similar tolerance elsewhere? While Arctic waters most often are characterised

444 by high $\mathrm{pH}$, studies show that low $\mathrm{pH}$ conditions do develop temporarily in some areas.

445 Corrosive conditions have been observed in the Canada Basin connected to sea ice melt 
446 (Yamamoto-Kawai et al., 2009), and low $\mathrm{pH} /$ high $\mathrm{pCO}_{2}$ conditions have also been observed 447 in extended areas along the Siberian coast (Anderson et al., 2011). Here, in the Laptev Sea, $448 \mathrm{CO}_{2}$ produced from microbial decomposition of organic matter originating from river run-off 449 has been shown to oversaturate the entire water column, even in the post spring bloom period 450 (Anderson et al., 2011). High $\mathrm{pCO}_{2} /$ low $\mathrm{pH}$ conditions have also been observed north of 451 Greenland (Jutterström \& Anderson, 2010). Thus, these areas could potentially function to 452 pre-condition copepods to low or at least variable $\mathrm{pH}$ increasing the possibility of species 453 wide tolerance to future OA.

454 Because we studied different developmental stages, our findings also contributed another 455 important observation. While CIVs responded significantly to decreasing $\mathrm{pH}$, we observed no 456 clear change in either ingestion or metabolic rate in CVs. Also in a previous study, Thor et al. 457 observed significant changes in the metabolic reaction to feeding at $\mathrm{pH}_{\mathrm{T}} 7.73$ compared to $458 \mathrm{pH}_{\mathrm{T}} 8.11$ in early copepodite stages (CII-CIII) but no changes in CVs (Thor et al., 2016). 459 Hildebrandt and colleagues found a similar lack of response of ingestion and metabolism in $C$. 460 glacialis CVs (Hildebrandt et al., 2014, Hildebrandt et al., 2016). But while this led the 461 authors to boldly conclude that shifts in seawater $\mathrm{pH}$ do not affect $C$. glacialis as a species, 462 our study highlights the need to refrain from conclusions based on studies of single 463 developmental stages. Such notion has been put forward previously by Dupont and colleagues 464 (2010). Their meta-analysis of OA effects in echinoderms showed that larvae and juveniles 465 mostly experience negative effects on growth and calcification while adults respond 466 positively. In crustaceans, stage-specific metabolic responses to OA were also found for 467 different larval stages in the European lobster (Small et al., 2015). Also Calanus exhibits 468 fundamental stage-specific metabolic differences, and in this respect the CV stage stands out. 469 While somatic growth is the main goal in the preceding stages, metabolism is largely 470 reconfigured to accommodate overwintering diapause in CVs. Ingestion rates were not much 471 higher than metabolic expenses in this stage (Fig. 3) and it seems that CVs were entering this 472 phase of physiological reconfiguration at the time of measurements. During diapause, $C$. 473 glacialis $\mathrm{CV}$ experience extracellular $\mathrm{pH}$ as low as 5.5 possibly as a result of metabolic 474 depression during hibernation (Freese et al., 2015). It is therefore quite conceivable that 475 mechanisms to counter low $\mathrm{pH}$ could be activated in this particular stage as part of the general 476 physiological reconfiguration to accommodate hibernation. This would render CVs 477 particularly unresponsive to ambient $\mathrm{pH}$. If such mechanisms require energy, as most 
478

479

480

481

482

483

484

485

486

487

488

489

490

491

492

493

494

495

496

497

498

499

500

501

502

503

504

505

506

507

508

509

510

511

512

513

514

515

516

517

physiological processes do, it would be evolutionarily beneficial to avoid their activation before they are needed.

\section{Acknowledgements}

We would like to thank the administrative and technical staff at the Sverdrup Station, NyÅlesund, the Kings Bay Marine Lab, Ny-Ålesund, and the Arctic Station (University of Copenhagen) in Qeqertarsuaq, Greenland for their invaluable support during experiments as well as the Norwegian Polar Institute's mapping section for help preparing the map in Figure 1. The study was financially supported by grants from the FRAM High North Research Centre for Climate and the Environment through the Ocean Acidification and Ecosystem Effects in Northern Waters Flagship and from the Norwegian Research Council (grant \# 225279), both to PT. SD was financially supported by the Linnaeus Centre for Marine Evolutionary Biology at the University of Gothenburg (http://www.cemeb.science.gu.se) and a Linnaeus grant from the Swedish Research Councils VR and Formas. PC was supported by an NSERC Discovery Grant Program and a FRQ-NT New University Researchers Start Up Program Grant.

\section{References}

Amap (2013) AMAP Assessment 2013: Arctic Ocean acidification, Oslo, Arctic Monitoring and Assessment Programme.

Anderson LG, Björk G, Jutterström S, Pipko I, Shakhova N, Semiletov I, Wåhlström I (2011) East Siberian Sea, an Arctic region of very high biogeochemical activity. Biogeosciences, 8, 17451754.

Anderson MJ (2001) A new method for non-parametric multivariate analysis of variance. Austral Ecology, 26, 32-46.

Arnkværn G, Daase M, Eiane K (2005) Dynamics of coexisting Calanus finmarchicus, Calanus glacialis and Calanus hyperboreus populations in a high-Arctic fjord. Polar Biology, 28, 528-538.

Azetsu-Scott K, Clarke A, Falkner K et al. (2010) Calcium carbonate saturation states in the waters of the Canadian Arctic Archipelago and the Labrador Sea. Journal of Geophysical Research: Oceans, 115, C11021.

Beaugrand G, Brander KM, Lindley JA, Souissi S, Reid PC (2003) Plankton effect on cod recruitment in the North Sea. Nature, 426, 661-664.

Bellerby RGJ, Silyakova A, Nondal G, Slagstad D, Czerny J, De Lange T, Ludwig A (2012) Marine carbonate system evolution during the EPOCA Arctic pelagic ecosystem experiment in the context of simulated Arctic ocean acidification. Biogeosciences Discuss., 2012, 15541-15565.

Bopp L, Resplandy L, Orr JC et al. (2013) Multiple stressors of ocean ecosystems in the 21st century: projections with CMIP5 models. Biogeosciences, 10, 6225-6245.

Brown JH, Gillooly JF, Allen AP, Savage VM, West GB (2004) Toward a metabolic theory of ecology. Ecology, 85, 1771-1789.

Båmstedt U, Gifford DJ, Irigoien X, Atkinson DE, Roman MR (2000) Feeding. In: Zooplankton methodology handbook. (eds Harris R, Wiebe PH, Lenz J, Skjoldal HR, Huntley ME) pp Page. Oxford, Academic Press. 
Caldeira K, Wickett ME (2005) Ocean model predictions of chemistry changes from carbon dioxide emissions to the atmosphere and ocean. Journal of Geophysical Research-Oceans, 110, CO9SO4.

Calosi P, De Wit P, Thor P, Dupont S (2016) Will Life find a Way? Evolution of Marine Species Under Global Change. Evolutionary Applications, n/a-n/a.

Calosi P, Melatunan S, Turner LM et al. (2017) Regional adaptation defines sensitivity to future ocean acidification. Nature Communications, 8, 13994.

Cao L, Caldeira K, Jain AK (2007) Effects of carbon dioxide and climate change on ocean acidification and carbonate mineral saturation. Geophysical Research Letters, 34, L05607.

Carroll SP, Hendry AP, Reznick DN, Fox CW (2007) Evolution on ecological time-scales. Functional Ecology, 21, 387-393.

Castonguay M, Plourde S, Robert D, Runge JA, Fortier L (2008) Copepod production drives recruitment in a marine fish. Canadian Journal of Fisheries and Aquatic Sciences, 65, 15281531.

Clark RA, Frid CLJ, Nicholas KR (2003) Long-term, predation-based control of a central-west North Sea zooplankton community. ICES Journal of Marine Science, 60, 187-197.

Clarke A (1980) A reappraisal of the concept of metabolic cold adaptation in polar marine invertebrates. Biological Journal of the Linnean Society, 14, 77-92.

David JR, Gibert P, Gravot E, Petavy G, Morin J-P, Karan D, Moreteau B (1997) Phenotypic plasticity and developmental temperature in Drosophila: Analysis and significance of reaction norms of morphometrical traits. Journal of Thermal Biology, 22, 441-451.

De Wit P, Dupont S, Thor P (2015) Selection on oxidative phosphorylation and ribosomal structure as a multigenerational response to ocean acidification in the common copepod Pseudocalanus acuspes. Evolutionary Applications, 1112-1123.

Dickson AG, Millero FJ (1987) A comparison of the equilibrium constants for the dissociation of carbonic acid in seawater media. Deep Sea Research Part A. Oceanographic Research Papers, 34, 1733-1743.

Dupont S, Dorey N, Thorndyke M (2010) What meta-analysis can tell us about vulnerability of marine biodiversity to ocean acidification? Estuarine, Coastal and Shelf Science, 89, 182-185.

Dupont S, Pörtner HO (2013) Get ready for ocean acidification. Nature, 498, 429-429.

Fabry VJ, Mcclintock JB, Mathis JT, Grebmeier JM (2009) Ocean acidification at high latitudes: The bellweather. Oceanography, 22, 160-171.

Fabry VJ, Seibel BA, Feely RA, Orr JC (2008) Impacts of ocean acidification on marine fauna and ecosystem processes. ICES Journal of Marine Science, 65, 414-432.

Fransson A, Chierici M, Anderson LG, Bussmann I, Kattner G, Peter Jones E, Swift JH (2001) The importance of shelf processes for the modification of chemical constituents in the waters of the Eurasian Arctic Ocean: implication for carbon fluxes. Continental Shelf Research, 21, 225242.

Fransson A, Chierici M, Hop H, Findlay HS, Kristiansen S, Wold A (2016) Late winter-to-summer change in ocean acidification state in Kongsfjorden, with implications for calcifying organisms. Polar Biology, 1-17.

Freese D, Niehoff B, Søreide JE, Sartoris FJ (2015) Seasonal patterns in extracellular ion concentrations and $\mathrm{pH}$ of the Arctic copepod Calanus glacialis. Limnology and Oceanography, 60, 2121-2129.

Frost BW (1972) Effect of size and concentration of food particles on the feeding behaviour of the marine planktonic copepod Calanus finmarchicus. Limnology and Oceanography, 17, 805815.

Grainger EH (1965) Zooplankton from the Arctic Ocean and adjacent Canadian waters. Journal of the Fisheries Research Board of Canada, 22, 543-564.

Halvorsen E (2015) Significance of lipid storage levels for reproductive output in the Arctic copepod Calanus hyperboreus. Marine Ecology Progress Series, 540, 259-265. 
Hansen MO, Nielsen TG, Stedmon CA, Munk P (2012) Oceanographic regime shift during 1997 in Disko Bay, Western Greenland. Limnology and Oceanography, 57, 634-644.

Havenhand J, Dupont S, Quinn GP (2010) Designing ocean acidification experiments to maximise inference. In: Guide for best practices for ocean acidification research and data reporting. (eds Riebesell U, Fabry VJ, Hansson L, Gattuso JP) pp Page. Brussels, European Commision.

Hellberg ME (2009) Gene flow and isoloation among populations of marine animals. Annual Review of Ecology Evolution and Systematics, 40, 291-310.

Hildebrandt N, Niehoff B, Sartoris FJ (2014) Long-term effects of elevated CO2 and temperature on the Arctic calanoid copepods Calanus glacialis and C. hyperboreus. Marine Pollution Bulletin, 80, 59-70.

Hildebrandt N, Sartoris FJ, Schulz KG, Riebesell U, Niehoff B (2016) Ocean acidification does not alter grazing in the calanoid copepods Calanus finmarchicus and Calanus glacialis. ICES Journal of Marine Science, 73, 927-936.

Hoegh-Guldberg O, Cai R, Poloczanska ES et al. (2014) The Ocean. In: Climate Change 2014: Impacts, Adaptation, and Vulnerability. Part B: Regional Aspects. Contribution of Working Group II to the Fifth Assessment Report of the Intergovernmental Panel of Climate Change. (eds Barros VR, Field CB, Dokken DJ, Mastrandrea MD, Mach KJ, Bilir TE, Chatterjee M, Ebi KL, Estrada YO, Genova RC, Girma B, Kissel ES, Levy AN, Maccracken S, Mastrandrea PR, White LL) pp Page. Cambridge, United Kingdom and New York, NY, USA, Cambridge University Press.

Ikeda T, Kanno Y, Ozaki K, Shinada A (2001) Metabolic rates of epipelagic marine copepods as a function of body mass and temperature. Marine Biology, 139, 587-596.

Ipcc (2013) Climate Change 2013: The Physical Science Basis. Contribution of Working Group I to the Fifth Assessment Report of the Intergovernmental Panel on Climate Change, Cambridge, UK and New York, USA, Cambrigde University Press.

Isari S, Zervoudaki S, Saiz E, Pelejero C, Peters J (2015) Copepod vital rates under CO2-induced acidification: a calanoid species and a cyclopoid species under short-term exposures. Journal of Plankton Research.

Jutterström S, Anderson LG (2010) Uptake of CO2 by the Arctic Ocean in a changing climate. Marine Chemistry, 122, 96-104.

Klekowski RZ, Weslawski JM (1991) Atlas of the marine fauna of Southern Spitsbergen.

Last JM (1980) The food of twenty species of fish larvae in the west-central North Sea, Lowestoft (UK), Ministry of Agriculture, Fisheries and Food.

Li W, Gao K (2012) A marine secondary producer respires and feeds more in a high CO2 ocean. Marine Pollution Bulletin, 64, 699-703.

Mackas DL, Goldblatt R, Lewis AG (1998) Interdecadal variation in developmental timing of Neocalanus plumchrus populations at Ocean Station P in the subarctic North Pacific. Canadian Journal of Fisheries and Aquatic Sciences, 55, 1878-1893.

Madsen SD, Nielsen TG, Hansen BW (2001) Annual population development and production by Calanus finmarchicus, C. glacialis and C. hyperboreus in Disko Bay, western Greenland. Marine Biology, 139, 75-93.

Mauchline J (1998) The biology of calanoid copepods, San Diego, Academic Press.

Mehrbach C, Culberson CH, Hawley JE, Pytkowicx RM (1973) Measurement of the apparent dissociation constant of carbonic acid in seawater at atmospheric pressure. Limnology and Oceanography, 18, 897-907.

Møller EF, Nielsen TG, Richardson K (2006) The zooplankton community in the Greenland Sea: Composition and role in carbon turnover. Deep-Sea Research Part I-Oceanographic Research Papers, 53, 76-93.

Möllmann C, Kornilovs G, Fetter M, Koster FW, Hinrichsen HH (2003) The marine copepod, Pseudocalanus elongatus, as a mediator between climate variability and fisheries in the Central Baltic Sea. Fisheries Oceanography, 12, 360-368. 
Nielsen TG, Kjellerup S, Smolina I, Hoarau G, Lindeque P (2014) Live discrimination of Calanus glacialis and C. finmarchicus females: can we trust phenological differences? Marine Biology, 161, 1299-1306.

Omori M, Ikeda T (1984) Methods in marine zooplankton ecology, New York, Wiley.

Pedersen SA, Hakedal OJ, Salaberria I et al. (2014) Multigenerational exposure to ocean acidification during food limitation reveals consequences for copepod scope for growth and vital rates. Environmental Science \& Technology, 48, 12275-12284.

Peijnenburg KTCA, Goetze E (2013) High evolutionary potential of marine zooplankton. Ecology and Evolution, 3, 2765-2781.

Pespeni MH, Sanford E, Gaylord B et al. (2013) Evolutionary change during experimental ocean acidification. Proc.Natl.Acad.Sci., 110, 6937-6942.

Peterson BJ, Holmes RM, Mcclelland JW et al. (2002) Increasing River Discharge to the Arctic Ocean. Science, 298, 2171-2173.

Pierrot D, Lewis E, Wallace DWR (2006) MS Excel program developed for CO2 system calculations. ORNL/CDIAC-105a., Oak Ridge, Tennesee, Carbon Dioxide Information Analysis Center, Oak Ridge National Laboratory, US Department of Energy.

Rastrick SP, Whiteley NM (2011) Congeneric amphipods show differing abilities to maintain metabolic rates with latitude. Physiological and Biochemical Zoology, 84, 154-165.

Raymond PA, Mcclelland JW, Holmes RM et al. (2007) Flux and age of dissolved organic carbon exported to the Arctic Ocean: A carbon isotopic study of the five largest arctic rivers. Global Biogeochemical Cycles, 21, GB4011.

Rey-Rassat C, Irigoien X, Harris R, Head R, Carlotti F (2002) Growth and development of Calanus helgolandicus reared in the laboratory. Marine Ecology Progress Series, 238, 125-138.

Riebesell U, Fabry VJ, Hansson L, Gattuso JP (2010) Guide to best practice for research for ocean acidification and data reporting, Luxembourg, Publications Office of the European Union.

Riisgaard K, Nielsen TG, Hansen PJ (2015) Impact of elevated pH on succession in the Arctic spring bloom. Marine Ecology Progress Series, 530, 63-75.

Rocha FB, Klaczko LB (2012) Connecting the dots of nonlinear reaction norms unravels the threads of genotype-environment interaction in Drosophila. Evolution, 66, 3404-3416.

Runge JA, Castonguay M, De Lafontaine Y, Ringuette M, Beaulieu JL (1999) Covariation in climate, zooplankton biomass and mackerel recruitment in the southern Gulf of St Lawrence. Fisheries Oceanography, 8, 139-149.

Runge JA, Fields DM, Thompson CRS et al. (2016) End of the century CO2 concentrations do not have a negative effect on vital rates of Calanus finmarchicus, an ecologically critical planktonic species in North Atlantic ecosystems. ICES Journal of Marine Science, 73, 937-950.

Sanford E, Kelly MW (2010) Local Adaptation in Marine Invertebrates. Annual Review of Marine Science, 3, 509-535.

Sibly RM, Calow P (1986) Physiological ecology of animals - an evolutionary approach, Oxford, Blackwell Scientific publications.

Small DP, Calosi P, Boothroyd D, Widdicombe S, Spicer JI (2015) Stage-specific changes in physiological and life-history responses to elevated temperature and pCO2 during the larval development of the European Lobster Homarus gammarus (L.). Physiological and Biochemical Zoology, 88, 494-507.

Steinacher M, Joos F, Frölicher TL, Plattner GK, Doney SC (2009) Imminent ocean acidification in the Arctic projected with the NCAR global coupled carbon cycle-climate model. Biogeosciences, 6, 515-533.

Strickland JD, Parsons TR (1972) A practical handbook of seawater analysis. Journal of the Fisheries Research Board of Canada, 167, 310.

Stumpp M, Hu M, Casties I, Saborowski R, Bleich M, Melzner F, Dupont S (2013) Digestion in sea urchin larvae impaired under ocean acidification. Nature Clim.Change, 3, 1044-1049.

Sunday JM, Calosi P, Dupont S, Munday PL, Stillman JH, Reusch TBH (2014) Evolution in an acidifying ocean. Trends in Ecology \& Evolution, 29, 117-125. 
Thoisen C, Riisgaard K, Lundholm N, Nielsen TG, Hansen PJ (2015) Effect of acidification on an Arctic phytoplankton community from Disko Bay, West Greenland. Marine Ecology Progress Series, 520, 21-34.

Thor P, Bailey A, Halsband C, Guscelli E, Gorokhova E, Fransson A (2016) Seawater pH predicted for the year 2100 affects the metabolic response to feeding in copepodites of the Arctic copepod Calanus glacialis. PLoS ONE, 11, e0168735.

Thor P, Dupont S (2015) Transgenerational effects alleviate severe fecundity loss during ocean acidification in a ubiquitous planktonic copepod. Global Change Biology, 21, 2261-2271.

Thor P, Koski M, Tang KW, Jónasdóttir SH (2007) Supplemental effects of diet mixing on absorption of ingested organic carbon in the marine copepod Acartia tonsa. Marine Ecology Progress Series, 331, 131-138.

Thor P, Nielsen TG, Tiselius P (2008) Mortality rates of epipelagic copepods in the post-spring bloom period in the Disko Bay, western Greenland. Marine Ecology Progress Series, 359, 151-160.

Thor P, Nielsen TG, Tiselius P et al. (2005) Post spring bloom community structure of pelagic copepods in the Disko Bay, Western Greenland. Journal of Plankton Research, 27, 341-356.

Thor P, Oliva EO (2015) Ocean acidification elicits different energetic responses in an Arctic and a boreal population of the copepod Pseudocalanus acuspes. Marine Biology, 162, 799-807.

Thor P, Wendt I (2010) Functional response of carbon absorption efficiency in the copepod Acartia tonsa Dana. Limnology and Oceanography, 55, 1779-1789.

Vargas CA, Lagos NA, Lardies MA et al. (2017) Species-specific responses to ocean acidification should account for local adaptation and adaptive plasticity. Nature Ecology \& Evolution, 1, 0084.

Walther K, Anger K, Pörtner HO (2010) Effects of ocean acidification and warming on the larval development of the spider crab Hyas araneus from different latitudes $\left(54^{\circ}\right.$ vs. $\left.79^{\circ} \mathrm{N}\right)$. Marine Ecology Progress Series, 417, 159-170.

Wassmann P, Kosobokova KN, Slagstad D et al. (2015) The contiguous domains of Arctic Ocean advection: Trails of life and death. Progress in Oceanography, 139, 42-65.

Whiteley NM (2011) Physiological and ecological responses of crustaceans to ocean acidification. Marine Ecology Progress Series, 430, 257-271.

Wittmann AC, Pörtner HO (2013) Sensitivities of extant animal taxa to ocean acidification. Nature Clim.Change, 3, 995-1001.

Wood HL, Sundell K, Almroth BC, Sköld HN, Eriksson SP (2016) Population-dependent effects of ocean acidification. Proceedings of the Royal Society of London B: Biological Sciences, 283.

Yamamoto-Kawai M, Mclaughlin FA, Carmack EC, Nishino S, Shimada K (2009) Aragonite Undersaturation in the Arctic Ocean: Effects of Ocean Acidification and Sea Ice Melt. Science, 326, 1098-1100.

Zervoudaki S, Frangoulis C, Giannoudi E, Krasakopoulou E (2014) Effects of low pH and raised temperature on egg production, hatching and metabolic rates of a Mediterranean copepod species (Acartia clausi) under oligotrophic conditions. Mediterranean Marine Science, 15, 7483. 


\section{Table 1}

713 Number of replicates per treatment combination: copepodite developmental stage (CIII, CIV,

$714 \mathrm{CV}$ ) of Calanus glacialis by nominal $\mathrm{pH}$ level according to our experimental design. When

715 different, numbers preceding that slash refer to ingestion rate measurements and number

716 following the slash refer to metabolic rate measurements. When only one value is indicated

717 the number of replicates were equal. A total number of 153 samples were included in analyses 718 of ingestion rate and a total of 170 in analyses of metabolic rates. By necessity the number of 719 replicates varied with the number of copepodites available.

720

\begin{tabular}{ccccccccccc}
$\begin{array}{c}\text { Copepodite } \\
\text { stage }\end{array}$ & Location & \multicolumn{1}{c}{ Nominal pH } \\
& & 8.2 & 8.0 & 7.8 & 7.6 & 7.4 & 7.2 & 7.0 & 6.6 & 6.4 \\
\hline CIII & Kongsfjord & $3 / 2$ & 3 & $1 / 2$ & 3 & $2 / 3$ & 2 & 3 & 1 & 1 \\
CIV & Kongsfjord & 4 & 4 & 2 & $4 / 3$ & 4 & $2 / 0$ & $4 / 3$ & 2 & 2 \\
& Billefjord & $4 / 3$ & $4 / 3$ & $2 / 4$ & 3 & 4 & 3 & 4 & & \\
& Disko Bay & $0 / 4$ & $3 / 1$ & 1 & 5 & 5 & 1 & 4 & $2 / 3$ & $3 / 4$ \\
& Kongsfjord & $4 / 3$ & 4 & $2 / 1$ & $3 / 4$ & 4 & 2 & 4 & 2 & $1 / 2$ \\
& Billefjord & $0 / 1$ & 1 & 1 & 1 & 1 & 1 & 1 & & \\
& Disko Bay & $0 / 3$ & $6 / 8$ & $2 / 5$ & 4 & 5 & $1 / 5$ & $3 / 5$ & $2 / 3$ & $2 / 3$ \\
\hline
\end{tabular}


723 Mean \pm standard deviations of carbonate chemistry parameters during incubations. $\mathrm{pH}_{\text {nom }}$ is

724 nominal $\mathrm{pH}$ treatment, $\mathrm{pH}_{\mathrm{T}}$ is total hydrogen scale $\mathrm{pH}, \mathrm{A}_{\mathrm{T}}$ is total alkalinity, and $p \mathrm{CO}_{2}$ is $\mathrm{CO}_{2}$

725 partial pressure. $\mathrm{A}_{\mathrm{T}}$ was measured only once in the $\mathrm{pH}_{\text {nom }} 7.5$ treatment once in the Billefjord 726 population experiment.

727

\begin{tabular}{|c|c|c|c|c|c|}
\hline $\mathrm{pH}_{\text {nom }}$ & $\begin{array}{l}\mathrm{T} \\
{ }^{\circ} \mathrm{C}\end{array}$ & S & $\mathrm{pH}_{\mathrm{T}}$ & $\begin{array}{c}\mathrm{A}_{T} \\
\mu \mathrm{mol} \mathrm{kg}^{-1}\end{array}$ & $\begin{array}{l}p \mathrm{CO}_{2} \\
\mu \text { atm }\end{array}$ \\
\hline \multicolumn{6}{|c|}{ Kongsfjord } \\
\hline 8.1 & $6.1 \pm 0.9$ & $34.0 \pm 0.1$ & $8.012 \pm 0.064$ & $2347 \pm 11$ & $450 \pm 95$ \\
\hline 7.9 & $6.0 \pm 0.7$ & $34.0 \pm 0.1$ & $7.851 \pm 0.062$ & $2351 \pm 14$ & $712 \pm 134$ \\
\hline 7.7 & $5.9 \pm 0.6$ & $33.9 \pm 0.1$ & $7.618 \pm 0.092$ & $2354 \pm 9$ & $1213 \pm 346$ \\
\hline 7.5 & $6.3 \pm 0.8$ & $34.0 \pm 0.1$ & $7.442 \pm 0.088$ & $2353 \pm 21$ & $1973 \pm 460$ \\
\hline 7.3 & $6.4 \pm 0.7$ & $34.0 \pm 0.1$ & $7.318 \pm 0.067$ & $2348 \pm 11$ & $2414 \pm 308$ \\
\hline 7.1 & $6.3 \pm 0.8$ & $34.0 \pm 0.1$ & $7.160 \pm 0.063$ & $2353 \pm 5$ & $3546 \pm 543$ \\
\hline 6.9 & $6.4 \pm 0.7$ & $34.0 \pm 0.1$ & $6.998 \pm 0.044$ & $2350 \pm 16$ & $5132 \pm 526$ \\
\hline 6.6 & $6.5 \pm 0.5$ & $34.0 \pm 0.1$ & $6.636 \pm 0.050$ & $2337 \pm 8$ & $11534 \pm 1368$ \\
\hline 6.4 & $6.3 \pm 0.4$ & $34.0 \pm 0.1$ & $6.445 \pm 0.039$ & $2332 \pm 6$ & $18567 \pm 2163$ \\
\hline \multicolumn{6}{|c|}{ Billefjord } \\
\hline 8.1 & $6.2 \pm 0.7$ & $34.0 \pm 0.1$ & $8.041 \pm 0.056$ & & $446 \pm 93$ \\
\hline 7.9 & $6.5 \pm 0.7$ & $34.0 \pm 0.1$ & $7.851 \pm 0.033$ & & $683 \pm 49$ \\
\hline 7.7 & $6.5 \pm 0.4$ & $34.0 \pm 0.1$ & $7.644 \pm 0.047$ & & $1119 \pm 178$ \\
\hline 7.5 & $6.9 \pm 0.7$ & $34.0 \pm 0.1$ & $7.497 \pm 0.034$ & $2322 \pm 3$ & $1536 \pm 154$ \\
\hline 7.3 & $6.5 \pm 0.4$ & $34.0 \pm 0.1$ & $7.337 \pm 0.036$ & & $2319 \pm 257$ \\
\hline 7.1 & $6.5 \pm 0.5$ & $34.0 \pm 0.1$ & $7.180 \pm 0.043$ & & $3336 \pm 392$ \\
\hline 6.9 & $6.4 \pm 0.4$ & $34.1 \pm 0.1$ & $7.036 \pm 0.041$ & & $4526 \pm 499$ \\
\hline \multicolumn{6}{|c|}{ Disko Bay } \\
\hline 8.1 & $3.9 \pm 0.3$ & $34.4 \pm 0.1$ & $8.001 \pm 0.059$ & $2280 \pm 0$ & $436 \pm 64$ \\
\hline 7.9 & $3.9 \pm 0.4$ & $34.4 \pm 0.1$ & $7.805 \pm 0.050$ & $2286 \pm 7$ & $721 \pm 91$ \\
\hline 7.7 & $3.6 \pm 0.6$ & $34.4 \pm 0.1$ & $7.627 \pm 0.046$ & $2293 \pm 0$ & $1112 \pm 128$ \\
\hline 7.5 & $3.9 \pm 0.7$ & $34.4 \pm 0.1$ & $7.431 \pm 0.056$ & $2287 \pm 7$ & $1774 \pm 250$ \\
\hline 7.3 & $3.6 \pm 0.5$ & 34.6 & $7.262 \pm 0.036$ & $2287 \pm 7$ & $2642 \pm 233$ \\
\hline 7.1 & $3.5 \pm 0.5$ & 34.6 & $7.099 \pm 0.020$ & $2293 \pm 0$ & $3865 \pm 194$ \\
\hline 6.9 & $3.6 \pm 0.6$ & 34.6 & $6.920 \pm 0.040$ & $2287 \pm 7$ & $5878 \pm 517$ \\
\hline 6.6 & $4.5 \pm 0.8$ & 34.6 & $6.562 \pm 0.037$ & $2280 \pm 0$ & $13325 \pm 1130$ \\
\hline 6.4 & $4.1 \pm 0.8$ & 34.6 & $6.403 \pm 0.077$ & $2280 \pm 0$ & $19456 \pm 3521$ \\
\hline
\end{tabular}


729 Table 3

730 Ingestion rate reaction norms of Calanus glacialis copepodite stage CIV. Results of the first

731 order regression model, $I R=\overline{I R}+g\left(p H_{T}-\overline{p H}_{T}\right)$ (David et al., 1997), where $\overline{I R}$ is mean

732 ingestion rate, $g$ is the slope, and $\overline{p H}_{T}$ is mean $\mathrm{pH}_{\mathrm{T}}$.

733

734

\begin{tabular}{clccccc} 
Stage & Location & $\begin{array}{c}\overline{I R} \\
\mu \mathrm{gC} \mu \mathrm{gC}^{-1} \mathrm{~d}^{-1}\end{array}$ & $\overline{p H}_{T}$ & $\begin{array}{c}g \\
\times 10^{-3}\end{array}$ & $\mathrm{r}^{2}$ & $P$ \\
\hline $\mathrm{CIII}$ & Kongsfjord & 0.1006 & 7.30 & 17.6 & 0.05 & $0.369^{+}$ \\
$\mathrm{CIV}$ & Kongsfjord & 0.0474 & 7.30 & 39.4 & 0.41 & $<0.001$ \\
& Billefjord & 0.0398 & 7.62 & 28.0 & 0.19 & 0.031 \\
& Disko Bay & 0.0456 & 7.30 & 7.13 & 0.04 & 0.323 \\
$\mathrm{CV}$ & Kongsfjord & 0.0271 & 7.24 & 13.8 & 0.11 & 0.111 \\
& Billefjord & 0.0234 & 7.51 & -2.23 & 0.02 & 0.808 \\
& Disko Bay & 0.0121 & 7.31 & -0.91 & 0.02 & 0.540 \\
\hline
\end{tabular}

${ }^{+}$Ingestion rates of CIIIs were best fitted with the second order regression model (see text). 


\section{Table 4}

736 Metabolic rate reaction norms of Calanus glacialis copepodite stage CIV. Results of the first

737 order regression model, $\dot{M} O_{2}=\overline{\dot{M}} O_{2}+g\left(p H_{T}-\overline{p H}_{T}\right)$ (David et al., 1997), where $\overline{\dot{M}} O_{2}$ is 738 mean metabolic rate, $g$ is the slope, and $\overline{p H}_{T}$ is mean $\mathrm{pH}_{\mathrm{T}}$.

\begin{tabular}{clccccc} 
Stage & Location & $\begin{array}{c}\overline{\dot{M}} O_{2} \\
\mu g C \mu \mathrm{gC}^{-1} \mathrm{~d}^{-1}\end{array}$ & $\begin{array}{c}\overline{p H}_{T} \\
\mathrm{x} 10^{-3}\end{array}$ & $\mathrm{r}^{2}$ & $P$ \\
\hline CIII & Kongsfjord & 0.0210 & 7.29 & 15.1 & 0.16 & 0.080 \\
$\mathrm{CIV}$ & Kongsfjord & 0.0206 & 7.30 & -6.81 & 0.15 & 0.043 \\
& Billefjord & 0.0254 & 7.62 & -10.2 & 0.23 & 0.014 \\
& Disko Bay & 0.0258 & 7.31 & -2.92 & 0.03 & 0.359 \\
$\mathrm{CV}$ & Kongsfjord & 0.0170 & 7.30 & 2.51 & 0.04 & 0.354 \\
& Billefjord & 0.0149 & 7.62 & -6.18 & 0.12 & 0.456 \\
& Disko Bay & 0.0231 & 7.31 & -3.81 & 0.04 & 0.236 \\
\hline
\end{tabular}

739 


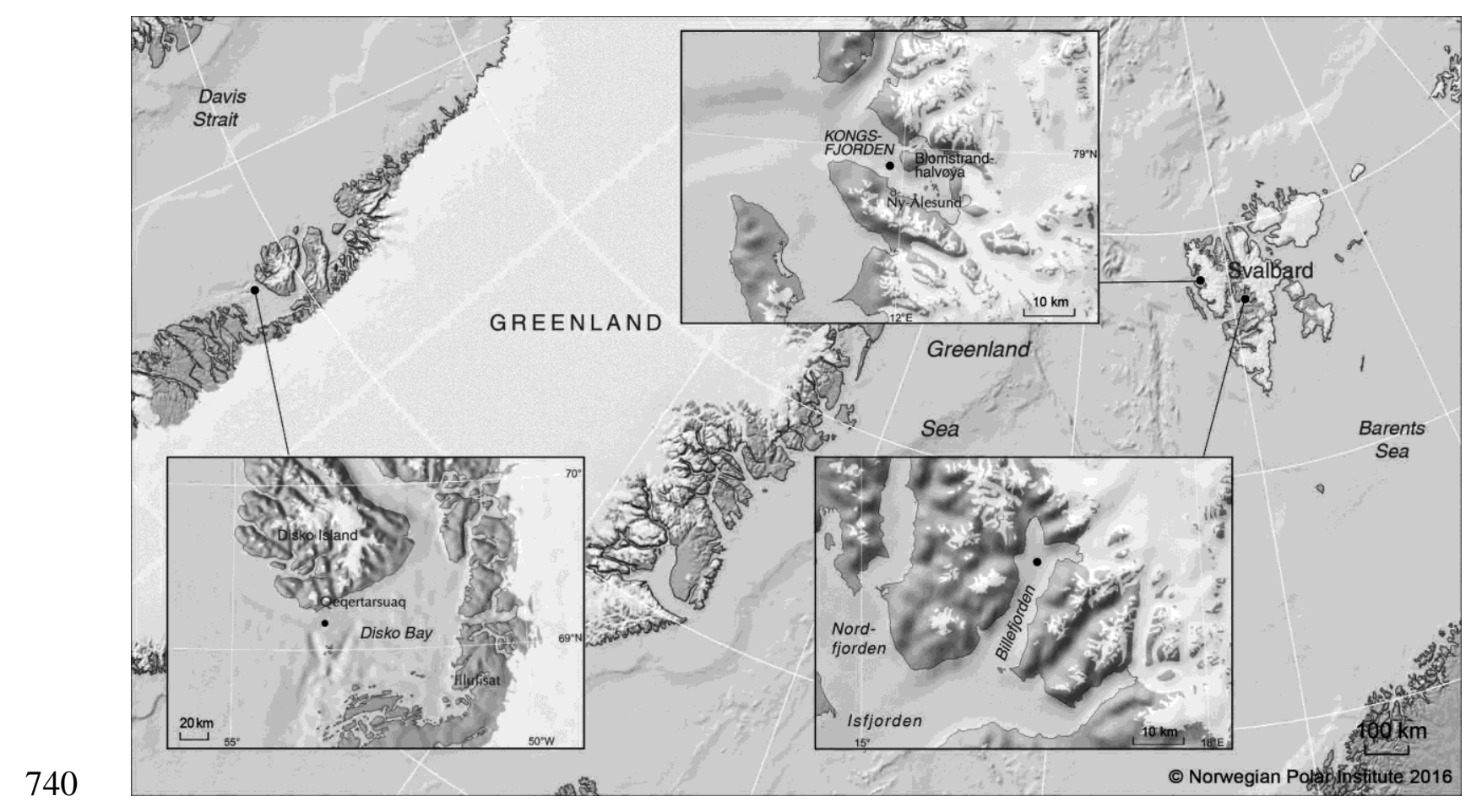

741 Figure 1. Study sites in Kongsfjord, Billefjord (Svalbard), and Disko Bay (West Greenland). 


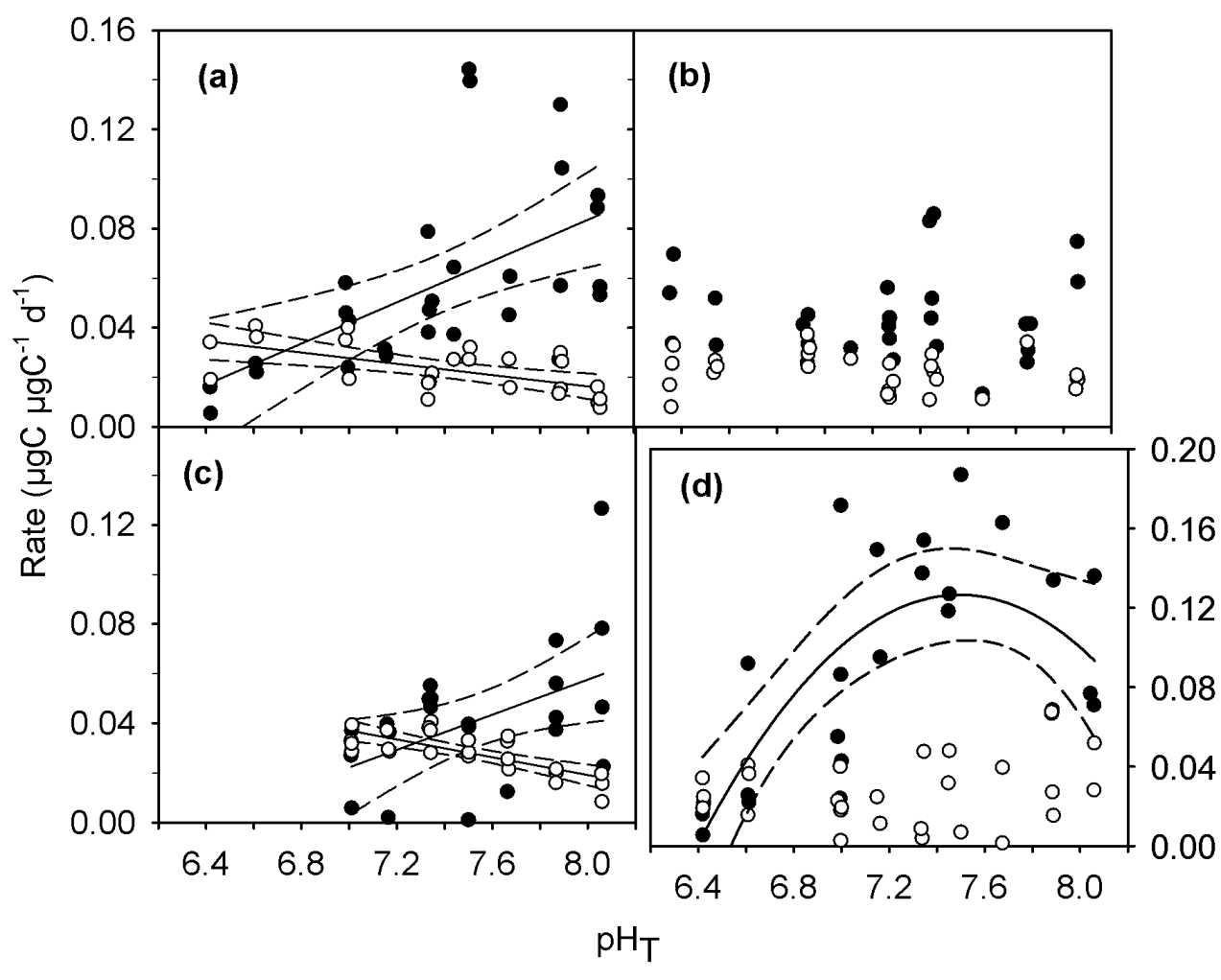

$\mathrm{pH}_{\mathrm{T}}$

744 Figure 2. Calanus glacialis copepodite stages CIII and CIV. Ingestion rates (filled circles) and 745 metabolic rates (open circles) vs. seawater $\mathrm{pH}_{\mathrm{T}}$ in the three populations. a) Kongsfjord CIVs, 746 b) Disko Bay CIVs, c) Billefjord CVs, and d) Kongsfjord CIIIs. Lines depict first or second 747 order reaction norms. Solid lines show predicted values and hatched lines show $95 \%$

748 confidence limits. Reaction norm parameters and statistics are shown in Tables 3 and 4. 


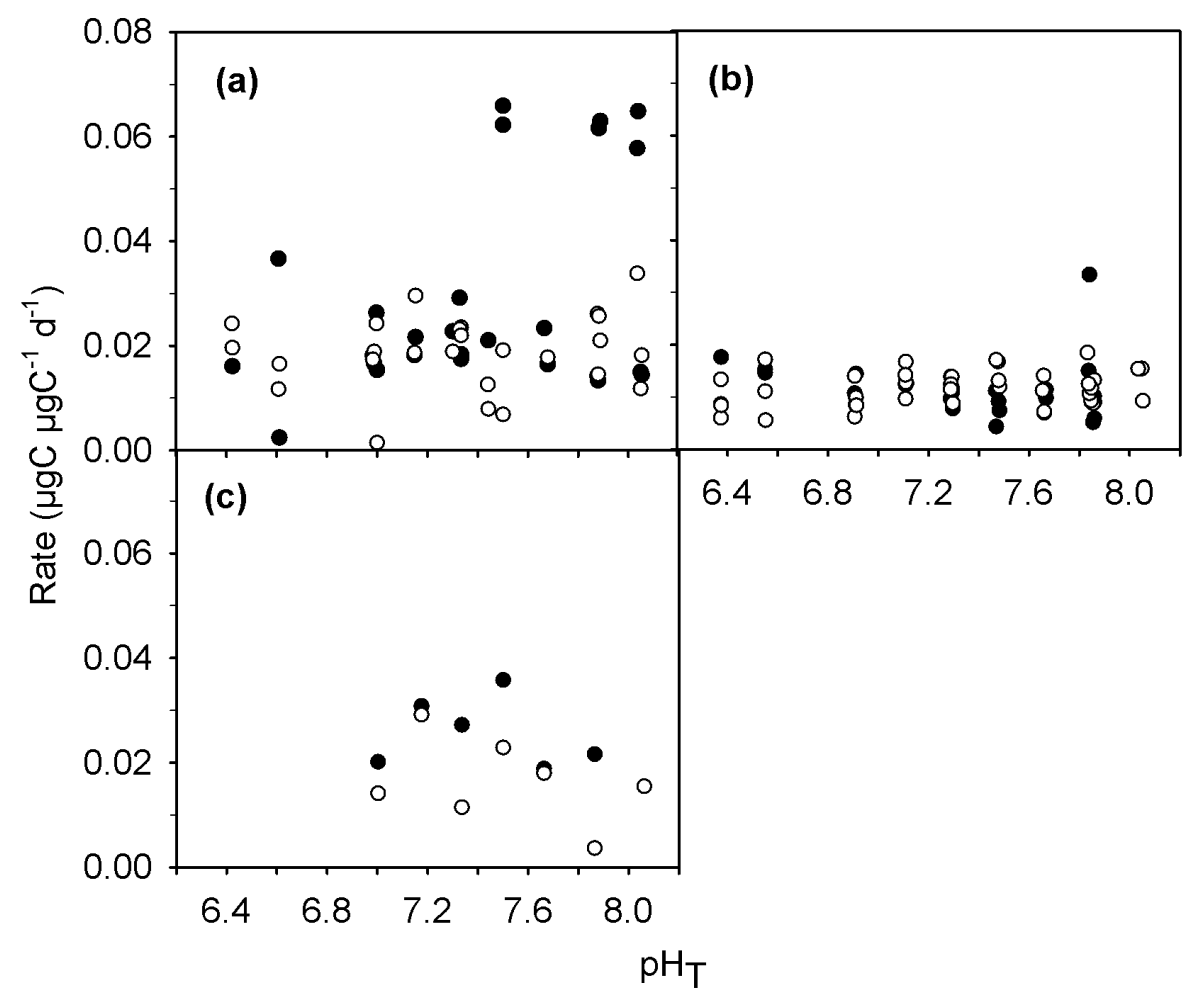

751 Figure 3. Calanus glacialis copepodite stage CV. Ingestion rates (filled circles) and metabolic 752 rates (open circles) $v s$. seawater $\mathrm{pH}_{\mathrm{T}}$ in the three populations investigated. a) Kongsfjord, b) 753 Disko Bay, and c) Billefjord. 